\title{
Conidia sporulation of Pyricularia oryzae in segments of wheat plants under six different temperatures
}

\author{
Marcos Kovaleski ${ }^{1}$ João Leodato Nunes Maciel $^{2 *}$ Gustavo Bilibio dos Santos ${ }^{3}$ \\ Alieze Nascimento da Silva $^{4}$ Carolina Cardoso Deuner $^{1}(\mathbb{D})$ \\ ${ }^{1}$ Programa de Pós-graduação em Agronomia, Universidade de Passo Fundo (UPF), Passo Fundo, RS, Brasil. \\ ${ }^{2}$ Embrapa Trigo, 99050-970, Passo Fundo, RS, Brasil. E-mail: joao.nunes-maciel@embrapa.br. "Corresponding author. \\ ${ }^{3}$ Faculdade de Agronomia e Medicina Veterinária, Universidade de Passo Fundo (UPF), Passo Fundo, RS, Brasil. \\ ${ }^{4}$ Programa de Pós-graduação em Agronomia, Universidade Federal de Santa Maria (UFSM), Santa Maria, RS, Brasil.
}

ABSTRACT: Wheat blast is known for developing itself more intensely under relatively high temperature conditions but many aspects related to its epidemiology remain unknown. The objective of this research was to evaluate the sporulative capacity of Pyricularia oryzae Triticum (Pot), the causal agent of wheat blast, in tissues of wheat plants under different temperatures degrees. Wheat plants of the cultivar Anahuac 75, susceptible to blast, were inoculated in the stage of flowering with conidial suspensions $\left(10^{5}\right.$ conidia/mL) of the Pot isolates Py 12.1 .209 and Py 12.1.132. Seven days after the inoculation, plants were cut in the following segments: leaves, stems and rachis (with blast severity ranging from 40 to $60 \%$ ). Groups of each one of the three plant segments with the lesions were disposed in Petri-dish moist chambers, that were submitted to six different temperature treatments $\left(18,21,24,27,30\right.$ and $\left.33{ }^{\circ} \mathrm{C}\right)$. The most appropriate model that related the conidia production with temperature was identified in the evaluations conducted with stems. The established equations allowed identifying that the highest production of conidia of Pot occurs between 24 and $27^{\circ} \mathrm{C}$.

Key words: wheat blast, conidial production, severity, sporulative lesions.

Esporulação de conídios de Pyricularia oryzae em segmentos de plantas de trigo sob seis diferentes temperaturas

\begin{abstract}
RESUMO: Sabe-se que a brusone do trigo ocorre preferencialmente em condições de temperaturas relativamente altas, porém muitos aspectos sobre a epidemiologia desta doença ainda permanecem desconhecidos. O objetivo deste trabalho foi avaliar a capacidade esporulativa de Pyricularia oryzae Triticum (Pot) em tecidos de plantas de trigo sob diferentes temperaturas. Plantas de trigo do cultivar Anahuac 75 , suscetivel à brusone, foram inoculadas no estádio do florescimento com suspensões de conidios dos isolados Py 12.1.209 e Py 12.1.132 de Pot $\left(10^{5}\right.$ conídios $\left./ \mathrm{mL}\right)$. Sete dias após a inoculação, as plantas foram cortadas e separadas em três tipos de segmentos: colmos, folhas e ráquis (com severidade de brusone variando de 40 a 60\%). Um grupo de cada desses três tipos de segmentos de planta contendo lesões foi disposto em câmara úmida. O material foi acondicionado em seis níveis de temperatura: 18, 21, 24, 27, 30 e $33{ }^{\circ} \mathrm{C}$. O modelo mais apropriado que relacionou a produção de conídios com temperatura foi identificado nas avaliações feitas nas amostras de colmo. As equações estabelecidas permitiram identificar que a maior produção de conídios de Pot ocorreu entre as temperaturas de 24 e $27^{\circ} \mathrm{C}$.

Palavras-chave: brusone do trigo, produção de conídios, severidade, lesões esporulativas.
\end{abstract}

Wheat blast, caused by the fungus Pyricularia oryzae Triticum (Pot; VALENT et al., 2019), represents one of the main problems for wheat production in Brazil. High temperatures and rainfall during the heading phase are determinant factors for the occurrence of great damages caused by wheat blast (REIS et al., 2013). In the Brazilian South region, especially in the Rio Grande do Sul State, the subtropical climate predominates, which interweaves humidity and low average temperatures in winter, and does not favor the development of blast in the fields. A different situation happens in the Central region, where a tropical climate occurs, with higher average temperatures, and thus blast emerges (MACIEL et al., 2014). In that region, the management of the sowing season has been a strategy to avoid coincidence of the following circumstance: heading phase still during the rainfall period.

Some of the main environmental factors associated with the occurrence of wheat blast 
epidemics have been evaluated in Brazil. In this sense, it is possible to highlight the works developed by ALVES et al. (2006) and CARDOSO et al. (2008). In the first, the importance of the Relative Humidity (RH) in the development of the disease was demonstrated, and it was verified that sporulation is favored when the temperature is $28^{\circ} \mathrm{C}$ combined with $\mathrm{RH}>90 \%$. CARDOSO et al. (2008) studied the relation among wheat blast development on the heads, duration of head-wetness and environmental temperature. It was shown that, at $28^{\circ} \mathrm{C}$, the minimum wetting time for wheat blast development is approximately $10 \mathrm{~h}$. Results obtained in both studies are important, but one question that remains unanswered is how much a wheat plant, or a wheat plant segment, can assume as source of inoculum producing conidia, considering the potential of each conidium to generate a new lesion of wheat blast. Therefore, the objective of this research was to quantify the sporulation of Pot on wheat plants under different temperatures.

The experiments were carried out at Embrapa Wheat, Passo Fundo, Brazil. A factorial experimental design with three replicates was used to evaluate the sporulation of Pot under six different temperature degree. The treatments were composed of the following three factors: 1) two isolates of Pot: $P y$ 12.1.209 and $P y 12.1 .132 ; 2)$ three plant segments: leaf, stem and rachis; and 3 ) six temperature degrees: $18,21,24,27,30$ and $33{ }^{\circ} \mathrm{C}$. All evaluations were conducted twice.

The plants used in the experiments belong to the wheat cultivar Anahuac 75, which is highly susceptible to blast (MACIEL et al, 2014). The preparation of the conidial inoculum of Pot was carried out at the Embrapa Wheat Plant Pathology Lab. The inoculum, at concentration of $10^{5}$ conidia $/ \mathrm{mL}$, was sprayed with a hand sprayer in the flowering phase (phase 63 in the Zadoks scale; ZADOKS et al. (1974)). Aerial parts of the plants were covered by the spraying conidial inoculum of Pot without runoff of drops. Plants were protected with plastic bags, left in the dark in the first $24 \mathrm{~h}$, and kept in a controlled environment with a temperature around $25^{\circ} \mathrm{C}$ and UR higher than $90 \%$. Seven days later, with ample presence of blast symptoms on the aerial part of the plants, the infected plant material was collected. Then, this material was cut and separated into three portions: leaves, stems, and rachis. The estimated severity of blast on these segments was between 40 and $60 \%$.

The subdivided infected plant material was weighed and randomly distributed in groups with five units of each plant segment. After being submitted to asepsis (with sodium hypochlorite (2.5\%) in the proportion of $1: 1(\mathrm{v} / \mathrm{v})$ for 1 minute, followed by two rinses with distilled and sterilized water), the groups with five segments were conditioned in moist chambers established in Petri dishes. The Petri dishes were placed in a BOD chamber (Biochemical Oxygen Demand) for $96 \mathrm{~h}$ under different temperature degrees, configuring the different treatments established in the study. After $96 \mathrm{~h}$, the segments were placed in plastic capped Falcon tubes containing $5 \mathrm{~mL}$ sterile water, which were agitated for $40 \mathrm{~s}$, at the maximum level in a MA 162 tube shaker $\left(\right.$ Marcon $^{\circledR}$ ) for the release of the Pot conidia. The sporulation of each treatment was quantified using an optical microscope and counting the conidia in a hematocitometer (Neubauer chamber). The amount of conidia was converted to the number of conidia produced per $\mathrm{g}$ of plant tissue.

All recordings obtained were submitted to analysis of variance and regression, testing quadratic and linear models using the Statistical Analysis System (SAS ${ }^{\circledR}$ software v.9.0, Cary, North Carolina). The regression analysis was performed with the data transformed to $\log (\mathrm{x}+1)$ and adapted to the quadratic polynomial curve: $\mathrm{Y}=\mathrm{B} 1 \mathrm{X}^{2}-\mathrm{B} 2 \mathrm{X}+\mathrm{B} 3$, where $\mathrm{Y}$ is the dependent variable $(\log (\mathrm{x}+1)$ conidia per gram of tissue) and $\mathrm{X}$ is the independent variable (temperature).

The analysis of variance of the data determined that there was interaction among the three factors evaluated (isolate, temperature and plant segment). The significance of these interactions demonstrates that the effects of the factors were not independent indicating that individual analysis was necessary for each factor established in the study, making also necessary to carry out post analysis of the interactions. Thus, the evaluations were made per isolate and for each plant segment. Considering the condition of the variable evaluated (conidia production/g of wheat plant tissue) to be quantitative and varying according to the temperature, which is also a quantitative parameter, the data were submitted to regression analysis.

The analyzes based on assessment of sporulation in the stems (Figure 1a) showed that were those plant segments that provided the most appropriate data to adjust the relation conidia production versus temperature to quadratic equations, with determination coefficients $\left(\mathrm{R}^{2}\right)$ of 0.7114 and 0.7967 for the isolates $P y \quad 12.1 .209$ and $P y$ 12.1.132, respectively.

The reproductive development of the isolate Py 12.1.209 on leaf infection (Figure 1b) is best expressed by the regression curve $\mathrm{Y}=-0.065 \mathrm{X}^{2}$ $+3.359 \mathrm{X}-35.769$, with $\mathrm{R}^{2}$ of 0.431 . The sporulation of the isolate $P y 12.1 .132$ on the leaves, was better 

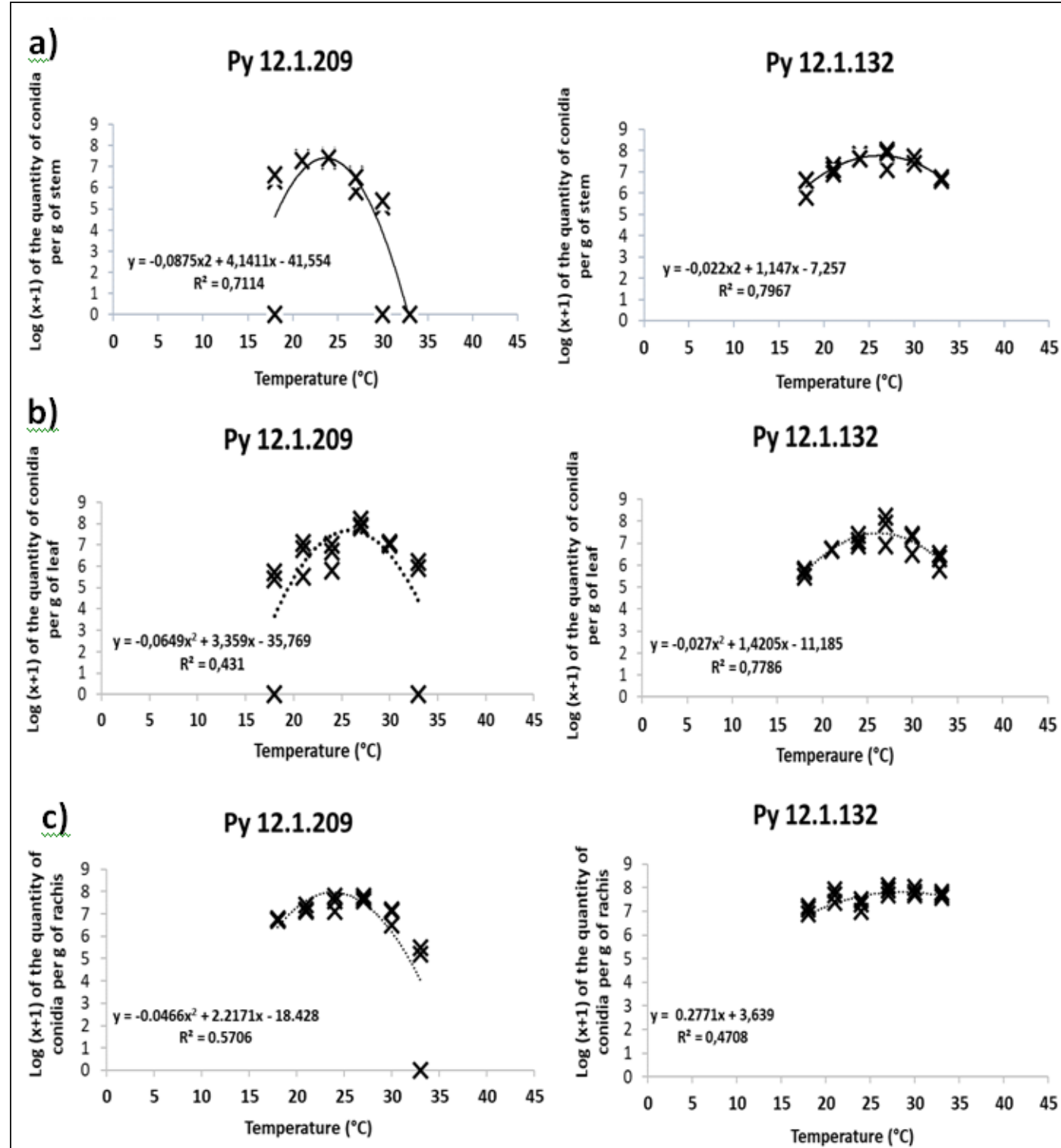

Py 12.1.132

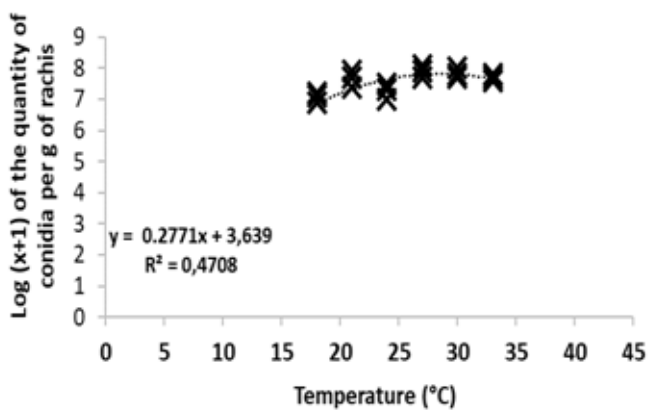

Figure 1 - Polynomial equations of the relation between temperature and conidia/g in the following wheat plant segments: a) stem; b) leaf; c) rachis, infected by isolates $P y$ 12.1.209 and $P y$ 12.1.132.

explained by the curve $\mathrm{Y}=-0.027 \mathrm{X}^{2}+1.42 \mathrm{X}-$ 11.184 , with a $\mathrm{R}^{2}$ of 0.7786 . When the sporulation was quantified in the rachis (Figure 1c), the isolate $P y$ 12.1.209 presented a $\mathrm{R}^{2}$ value of 0.5706 for the most adjusted quadratic equation which is the following, $\mathrm{Y}=-0.0465 \mathrm{X}^{2}+2.217 \mathrm{X}-18.42$. In the case of the isolate $P y 12.1 .132$ in the rachis, there was a difference in relation to the regression model more adjusted to explain the relation between the temperature factor and the sporulation variable. The best equation was linear, which is represented by $\mathrm{Y}=0.277 \mathrm{X}+3.639$ and with an $\mathrm{R}^{2}$ of 0.4708 .

On average for the two tested isolates, the conidia production at $18,21,24,27,30$ and 33 ${ }^{\circ} \mathrm{C}$ was, respectively, $1.92 \times 10^{6}, 9.45 \times 10^{6}, 1.28 \times 10^{7}$, $3.08 \times 10^{7}, 1.23 \times 10^{6}$ and $5.0 \times 10^{6}$ conidia per gram of plant tissue. The established equations allowed to identify that the highest production of Pot conidia occurred between 24 and $27^{\circ} \mathrm{C}$, independent of the isolate and the plant segment. In this sense, ALVES et 
al. (2006), determined that pathogen sporulation was higher at $28{ }^{\circ} \mathrm{C}$ than at $23{ }^{\circ} \mathrm{C}$; although, the variable analyzed in the study was not the same as the present study (conidia per gram of plant tissue). Conversely, CARDOSO et al. (2008) determined that the best development of the fungus as pathogen of wheat heads occurred at $28^{\circ} \mathrm{C}$.

Our initial expectation was that it would be possible to relate sporulation of Pot and temperature to the three types of segments used in the study. However, this condition was only verified for the assessments made in the stems. In the case of quantified sporulation in the rachis, and for the isolate Py 12.1.209 in the leaf, the $\mathrm{R}^{2}$ values did not reach significant statistical levels. The most probable cause for this situation must be associated to the higher variation in the proportion between the sporulative and the non-sporulative areas in the samples used in the study, represented by the segments of leaf or rachis, even though the blast severity was relatively homogeneous on the surface of those samples $(40-60 \%)$.

The results obtained in the present study help to better measure how much the temperature variable, affects the reproductive performance of Pot and; consequently, the formation of inoculum for wheat blast. In practice, results shown here represent technical and scientific support for recommendations of wheat fields' management. Among these recommendations, it is possible to mention the sowing at times of the year that, for example, do not allow that the heading phase occurs at times when the temperature is more favorable to the fungus sporulation, considering that in that phase the damages caused by the disease has been greater.

\section{ACKNOWLEDGMENTS}

This work was carried out with the support and funding of Embrapa (Project SEG n ${ }^{\circ}$ 12.16.04.009.00.00); CNPq, Conselho Nacional de Desenvolvimento Científico e Tecnológico - Brasil; and Coordenação de Aperfeiçoamento de Pessoal de Nível Superior (CAPES), Brasil - Finance code 001. JLNM and GBS have scholarships from $\mathrm{CNPq}$ and ANS from CAPES.

\section{DECLARATION OF CONFLICT INTERESTS} OF

The authors declare no conflict of interest. The founding sponsors had no role in the design of the study; in the collection, analyses, or interpretation of data; in the writing of the manuscript, and in the decision to publish the results.

\section{AUTHORS' CONTRIBUTIONS}

All authors contributed equally for the conception and writing of the manuscript. All authors critically revised the manuscript and approved of the final version.

\section{REFERENCES}

ALVES, K. J. P. et al. Influência da temperatura e da umidade relativa do ar na esporulação de Magnaporthe grisea em trigo. Fitopatologia Brasileira, Brasília, v.31, n.6, p.579-584, 2006. Available from: $<$ http://www.scielo.br/pdf/fb/v31n6/a07v31n6.pdf > . Accessed: Oct. 31, 2019. doi: 10.1590/S0100-415820060006 00007 .

CARDOSO, C. A. de A. et al. Development of a warning system for wheat blast caused by Pyricularia grisea. Summa Phytopathologica. Botucatu, v.34,n.3,p.216-221,2008. Available from: $<$ http://www.scielo. $\mathrm{br} /$ scielo.php?script=sci arttext\&pid=S0100-54052008000300002>. Accessed: Apr. 26, 2019. doi: 10.1590/S0100-54052008000300002.

MACIEL, J. L. N. et al. Population structure and pathotype diversity of the wheat blast pa-thogen Pyricularia oryzae 25 years after its emergence in Brazil. Phytopathology, v.104, n.1, p.95-107, 2014. Available from: < https://www.ncbi.nlm.nih.gov/ pubmed/23901831>. Accessed: May, 19, 2019. doi: 10.1094/ PHYTO-11-12-0294-R.

REIS, E. M. et al. Brusone do trigo-ciclo da doença. 2013. Available from: <http://www.orse- mentes.com.br>. Accessed: May, 11, 2019.

VALENT, B. et al. Pyricularia graminis-tritici is not the correct species name for the wheat blast fungus: response to Ceresini et al. (MPP 20:2). Molecular Plant Pathology, v.20, n.2, p.173179, 2019. Available from: <https://www.ncbi.nlm.nih.gov/pmc/ articles/ PMC6637902/pdf/MPP-20-173.pdf > . Accessed: Nov. 03, 2019. doi: $10.1111 / \mathrm{mpp} .12778$.

ZADOKS, J. C. et al. A decimal code for the growth stages of cereals. Weed Research, Kansas, v.14, n.6, p.415-421, 1974. Available from: <https://onlinelibrary.wiley.com/doi/ abs/10.1111/j.1365-3180.1974.tb01084.x>. Accessed: May, 10, 2019. doi: 10.1111/j.1365-3180.1974.tb01084.x. 